\title{
Entre novidades úteis e graciosas velharias: como a obra literária se relaciona dialeticamente à história
}

Fecha de recepción: 1/8/2020.

Fecha de aceptación: 15/10/2020.

\section{Resumo}

Este texto procura analisar o romance brasileiro Quarup, escrito por Antonio Callado e publicado em 1967, a partir da análise da ambiência da Farmácia Castanho e do personagem Ramiro Castanho, elementos extremamente significativos dessa obra e que aparecem no segundo e terceiro capítulos. Tentar-se-á relacioná-los ao conceito de modernidade conservadora, ou modernidade reflexa, expressões defendidas por Darcy Ribeiro, Renato Ortiz, Antonio Candido, Roberto Schwarz, entre outros autores que serão contemplados aqui. Esta obra foi escrita em um momento conturbado do Brasil. No país, ditadura militar já instaurada, prisões, censura e o controle social eram temas reais, marcavam um regime político extremamente autoritário e violento que durou aproximadamente 20 anos. Após ler Quarup temos uma outra dimensão sobre o país, temos condições de perceber as contradições inerentes à modernidade e percebemos o porquê de o Brasil não caminhar, de fato, rumo a um progresso efetivo. Ao superar o caráter documental e se realizar de forma estética, Quarup capta a lógica de funcionamento de uma sociedade regida pela dialética entre modernização e atraso. Defendemos que Quarup capta essas contradições desse país que avança pouco e lentamente, pois, ao mesmo tempo em que tenta progredir, mantém suas raízes presas ao passado, isto é, mantém velharias, mas as ornamenta com novidades aparentemente úteis. 


\title{
Among useful novelties and graceful old things: how literary work relates dialectically to history
}

\begin{abstract}
This text seeks to analyze the Brazilian novel Quarup, written by Antonio Callado in 1967 and, more specifically, Farmácia Castanho and the character Ramiro Castanho, extremely significant elements of this work and that appear in the second and third chapters. We will try to relate them to the concept of conservative modernity, or reflex modernity, expressions defended by Darcy Ribeiro, Renato Ortiz, Antonio Candido, Roberto Schwarz, among other authors that will be contemplated here. This work was written in a troubled time in Brazil. In the country, military dictatorship already in place, prisons, censorship and social control were real issues, marked an extremely authoritarian and violent political regime that lasted approximately 20 years. After reading Quarup we have another dimension about the country, we are able to perceive the contradictions inherent to modernity and we understand why Brazil does not, in fact, walk towards effective progress. By overcoming the documentary character and being carried out in an aesthetic way, Quarup captures the logic of functioning of a society governed by the dialectic between modernization and backwardness. We argue that Quarup captures these contradictions of this country that keeps its roots stuck to the past while trying to progress and, being stuck in the past, it advances little and slowly, that is, it keeps old things, but adorns them with apparently useful news.
\end{abstract}

Keywords: Quarup; Modernity; Delay; Documentary character; Aesthetic shape.

A persistência do antigo em contraste com o novo, de acordo com Schwarz (1977: 77), é um fato geral em todas as sociedades capitalistas. Entretanto, para os países colonizados e depois subdesenvolvidos, como o Brasil, "ele é central e tem força de emblema”. Isto se explica, pois, estes países “foram incorporados ao mercado mundial - ao mundo moderno - na qualidade de econômica e socialmente atrasados, de fornecedores de matéria prima e trabalho barato. A sua ligação ao novo se faz através do atraso social". O moderno, como no caso do Brasil, não resulta da superação do atraso, mas é o próprio atraso que impulsiona a modernização. O arcaico, nesse sentido, é que teria sido responsável por alavancar o processo de acumulação e expansão do capitalismo moderno brasileiro. Sobre esse caráter conservador, que predomina em todo subcontinente, Antonio Candido (1990) também se aprofunda e afirma que a história da América Latina é um rol de crimes e abusos, porque as suas classes dirigentes são visceralmente conservadoras, e o conservantismo é incompatível com as nossas necessidades. Segundo Candido, é tão poderosa a natureza do conservantismo, como produto estrutural da sociedade predatória baseada no escravismo, que na América Latina todos são conservadores, até os revolucionários. 
Darcy Ribeiro em $O$ povo brasileiro (2006: 150) no capítulo intitulado "O arcaico e o moderno" afirma que "a passagem do padrão tradicional, tornado arcaico, ao padrão moderno opera a diferentes ritmos em todas as regiões do Brasil, mas mesmo as mais progressivas se veem tolhidas e reduzidas a uma modernização reflexa”. No entanto, ainda segundo Ribeiro (2006), isso não significa que haja uma resistência à mudança, mas sim, uma resistência apenas das classes dominantes, que mantêm seus interesses fundados em uma estrutura arcaica. 0 processo de industrialização, por exemplo, não teve um caráter transformador, como ocorreu em outras sociedades. "Ao contrário do que ocorre nas sociedades autônomas, aqui o povo não existe para si, e sim para outros" (Ribeiro, 2006: 227). Basta constatar que, no final do século XX, a sociedade brasileira apresentava cerca de $40 \%$ da população "compondo níveis de qualificação e rendimento de uma moderna sociedade industrializada, enquanto $60 \%$ encontrava-se relegada a uma condição econômica e educacional extremamente primitiva" (Jaguaribe, 1989: 26).

A modernização experimentada pelas nações desenvolvidas, como a França, transformou de fato o destino histórico dos homens, desenvolvendo suas forças produtivas; a sociedade, em geral, se expandiu e se transformou. Já em países, como o Brasil, a burguesia nacional é portadora de um "moderado espírito modernizador, que se utiliza das transformações capitalistas para reforçar seus interesses estamentais" (Ortiz, 1991: 17). Isto significa que o "moderado espírito modernizador" aqui não altera o destino humano, não o expande e tampouco o transforma, ao contrário, explora e exclui o homem, restringindo-o de usufruir das mudanças trazidas pela modernização.

Neste artigo será analisado o romance Quarup, escrito por Antonio Callado, em 1967. Esta obra foi escrita em um momento conturbado do Brasil. No país, ditadura militar já instaurada, prisões, censura e o controle social eram temas reais, mas que ainda não alcançavam a ferocidade do período posterior ao AI-5 (Ato Institucional número 5, que fechou o Congresso e intensificou a repressão), que chegaria em 1968. O período foi marcado por um regime político extremamente autoritário, violento e conservador, que durou aproximadamente 20 anos. O romance inicia-se na década de 50, época em que a palavra desenvolvimento tornou-se central e a euforia modernizadora marcou o narrar da história. No entanto, esse desenvolvimento foi interrompido. Se o Brasil, nesse período, sonhava com a superação do atraso e da sua condição subalterna e se havia, na realidade concreta, possibilidades para tal, a elite brasileira puxará os freios dessa modernização e o país será emperrado pelo golpe militar, em 64: o golpe apresentou-se como "uma gigantesca volta do que a modernização havia relegado, a revanche da província, dos pequenos proprietários, dos ratos de missa, etc" (Schwarz, 1978: 71).

O Brasil narrado em Quarup transfigura esse processo modernizador que se dá por meio de arrancadas de progresso e estagnações de atraso, como se verá a seguir, na análise de elementos do texto que traduzem essa questão.

Em Quarup, o personagem Ramiro, pequeno-burguês capitalista, é dono da farmácia Castanho e figura a modernização arcaica, ou reflexa, do país, baseada 
em moldes conservadores. 0 romance diz que o atraso brasileiro é estrutural e sistêmico, algo necessário para o desenvolvimento, de acordo com a lógica das classes dominantes. A forma como Ramiro se expressa, seus pensamentos e suas teses sobre o país, suas ações, suas crenças, sua ligação com o tradicional e suas ambiguidades, tudo nele demonstra que o Brasil, apesar de seus avanços, ainda está longe de uma transformação profunda, pois resiste, fortemente, à superação de seu passado e desempenha um papel reacionário nesse processo. Segundo Santos (1999: 160), a visão deste personagem "coincide com o ponto de vista da elite que dirige o Estado nacional, sem conhecimento prático da vida do povo e dos grupos étnicos do país", e está voltada para seus interesses individuais. As grandes contradições do mundo burguês, por meio de situações típicas, perpassam os personagens, como se essas contradições fossem seus próprios problemas, vividos de uma forma individual.

Ramiro herdou a Farmácia Castanho do pai que, por sua vez, também a ganhou de herança da família. É importante ressaltar que a única personagem do romance que tem sobrenome é Ramiro, assim como a farmácia herdada também: Castanho. Conserva-se o sobrenome de uma família também conservadora e tradicional e este sobrenome faz com que sobrevivam no tempo. De acordo com Magalhães (2001: 1), "a tradição é a conservação do já vivido das relações sociais, que estará sempre em luta com as novas formas que se apresentam, como o momento de questionamento do já posto". É, como observa Lukács (1978: 203), "a contraditoriedade inerente às relações sociais entre o velho e o novo. A vida reproduz sempre o velho, produz incessantemente o novo, a luta entre o velho e o novo penetra em todas as manifestações da vida".

Na farmácia, ele guarda remédios antigos do século XIX e toda sua estrutura conserva propositalmente "graciosas velharias", apesar de ter se modernizado com "novidades úteis", segundo afirma a própria personagem. No diálogo entre Ramiro e Nando, o protagonista do romance, percebe-se que o novo e o velho, o arcaico e o moderno, o passado e o presente se fundem em uma mesma estrutura: "esplêndida a ideia de conservar a Farmácia antiquada - disse Nando. - Eu pretendo conservá-la assim eternamente - respondeu Ramiro. Mesmo depois da minha morte" (Callado, 1984: 131). A recuperação dessas formas arcaicas, antiquadas, testemunha o conflito do processo modernizador no Brasil. São elementos que insistem em resistir apesar das "novidades úteis". O adjetivo "útil” também é importante para essa interpretação. Se é útil, subentende-se que o é para alguém, mas essa utilidade não é generalizável. Quem determina o que é ou não utilitário é o próprio Ramiro, sem intervenções de fora, sem tampouco mexer na estrutura, já tão antiquada quanto uma família de Castanhos.

Ramiro mantém os pés presos ao passado, ao mesmo tempo em que avança, comedidamente, com o progresso dos medicamentos e as novidades que ele mesmo utiliza na farmácia. Porém, essas inovações que ele traz para seu estabelecimento não se sobrepõem a sua coleção de antiguidades médicas, "fórmulas tão boas ou melhores que as de hoje." (Callado, 1984: 133). Saudosista e burocrata, este personagem demonstra que "entre o passado e o presente não houve transformação radical". 
Ramiro vive no Rio de Janeiro: em um apartamento luxuoso, onde promove festas regadas à lança perfume e jantares elegantes servidos por seus criados. Cheira a remédios, o que faz parecer, para Nando, "o odor de uma família de médicos e farmacêuticos". Mais uma vez, uma clara referência a um passado que permanece, como relíquia, no presente. Este passado está presente no aroma, no cheiro vivo e novo de um perfume antigo, como também está no sobrenome que a família carrega como tradição.

Ramiro também tem plena consciência de sua condição privilegiada e não quer abrir mão dela: "Então não exagera (Otávio). Não mete o povo no porre dos grã-finos e da classe média" (Callado, 1984: 123). Representa uma classe social conservadora, que vive de renda, não trabalha e também não abre mão de seus privilégios. Habituado ao seu posto sabe "quem precisa chaleirar, quem é que se pode dominar diretamente, quem é que não vai nem a gancho". E reflete: "Por que passar a vida inteira em luta contra esses movimentos naturais?" (Callado, 1984: 103). Vemos nele a caricatura do pequeno-burguês capitalista pela qual, por trás de um discurso ameno, cordial e amigável, revela-se, como também aponta Lukács (2010: 60), "a viscosidade, ao mesmo tempo covarde, desse pequeno burguês":

- Tio Ramiro tem dinheiro. Tem apartamentos e até hoje conserva a Farmácia Castanho, que era do pai dele. Mas nunca ajudou os pobretões da família. Agora, que o Ministro Gouveia caiu nas boas graças do governo, tio Ramiro empregou todo mundo, a família inteira. Eu sou funcionária do Ministério por concurso, sabe? Tio Ramiro arranjou todas as respostas às perguntas da prova que eu prestei. Depois me requisitou para secretária dele.

- Um bom tio, disse Nando sem saber que outra coisa dizer.

- Bom com o dinheiro do governo, disse Vanda (Callado, 1984: 100).

Ramiro tem dinheiro, apesar de nunca ter trabalhado, mas nunca ajudou os pobretões da família. Só é bom com o dinheiro do governo, como pondera a sobrinha, que é funcionária pública graças às respostas das perguntas que Ramiro "arranjou”.

A própria expressão "criado", que ele usa para tratar dos seus empregados, também demonstra essa inconformidade com o momento da narrativa. "Criado" remete a uma ideia de servidão, utilizada entre senhores e escravos. Estamos no início da década de 1950, muito além do período colonial. No entanto, a áurea do período ainda paira sobre o país, principalmente na consciência da classe burguesa. Assim afirma Sérgio Buarque de Holanda (1995: 177), corroborando esta ideia: "o Estado brasileiro preserva como relíquias respeitáveis algumas das formas exteriores do sistema tradicional e a imagem do nosso país não pode, até hoje, desligar-se muito do espírito imperial". Esse "espírito imperial”, apesar da ideia fantasmagórica que ele sugere, não está extinto de todo, pois, como se viu anteriormente, a tradição conservadora no Brasil se sustenta por meio do equilíbrio entre realidades tradicionais e profundas, como a de senhores e escravos; Ramiros e seus criados, velharias e novidades úteis. 
Ramiro Castanho mantém a sua farmácia antiquada e pretende conservá-la assim eternamente para depois de sua morte "metê-la num livro: biografia de uma farmácia”. É lá, em seu museu, como costuma descrevê-la, que Ramiro guarda antigos aparelhos e medicamentos que curavam doenças do passado. Olhar para a farmácia como um museu também traz à tona a ideia de olhar para a própria história como um museu, sem relações entre passado e presente, agarrandose às bandeiras do reacionarismo para frear as mudanças.

A personagem não supera os paradigmas e é limitado ao seu contexto histórico. Avançar, portanto, seria superar esses paradigmas que vão se tornando envelhecidos, fora de contexto. Se Ramiro não os supera, isso denota seu conteúdo reacionário, apesar de demonstrar certo apresso pelo progresso técnico: "Esta combinação, que é uma das marcas do nosso tempo, torna ambígua a noção de progresso" (Schwarz, 1978: 43).

Além deles, há na farmácia produtos de laboratórios franceses, "remédios velhos e já sem aroma ou corpo, como vinhos descobertos por arqueólogos em escavações" (Callado, 1984: 132). A presença desse sentimento saudosista impede Ramiro de avançar e conserva a drogaria no seu estado primitivo.

Conforme o texto avança, o narrador vai soltando as amarras do personagem e o deixa livre para esboçar suas ideias. Sua fisionomia intelectual começa a ganhar forma. Para Ramiro, a salvação do país é a drogaria, e a venda de remédios, um negócio de primeira ordem. Ele atua como a indústria farmacêutica que:

Visando à modernização arcaica, transforma a doença em fonte de bons negócios, como a guerra. E, portanto, não seria interessante evitá-la. Torna-se conveniente manter um grau de doença que dinamize a produção e o comércio de remédios, remunere os investimentos em fábricas de equipamentos hospitalares e os próprios hospitais (Santos, 1999: 164).

A concepção de mundo da personagem é que o Brasil é "um grande hospital e o brasileiro tem vocação para a doença” (Callado, 1984: 128). Essa afirmação, somada à ideia de que a salvação do país é a drogaria, são afirmações fatalistas, deterministas, típicas da perspectiva burguesa decadente, que aponta para uma impossibilidade de futuro, segundo György Lukács em Marx e o problema da decadência ideológica (2010):

A decadência foge covardemente da expressão da realidade e mascara a fuga mediante o recurso ao "espírito científico objetivo" ou a ornamentos românticos. Em ambos os casos, é essencialmente acrítica, não vai além da superfície dos fenômenos, permanece no imediatismo e cata ao mesmo tempo migalhas contraditórias de pensamento, unidas pelo laço de ecletismo (Lukács, 2010: 65).

É um impulso dos apologetas falsificar a realidade de acordo com as necessidades econômicas e políticas da própria burguesia. Ramiro aproxima-se da realidade de forma unilateral e, por isso, não tem uma visão em profundidade. Seu 
pensamento, apologeta, não é fecundado pelas contradições da vida concreta. Considerar que não há nada para além da drogaria, neste caso, é colocar-se ao lado dos reacionários que impedem os avanços e as mudanças. São afirmações que reforçam a impossibilidade das ações humanas no mundo.

A força humana, segundo Rosa (2015: 87) “está apagada, adormecida, inutilizada por uma força que determina a vida". Se, para que haja progresso, são necessárias mudanças históricas significativas e estas são realizadas pelas ações humanas, estando essas ações paralisadas, com "cinquenta milhões de homens, mulheres e crianças entre lençóis, olhando para o teto, em cinquenta milhões de leitos de ferro branco" (Callado, 1984: 131), então, também não há possibilidade de mudanças concretas.

Ramiro não se interessa pelas mudanças, mas pela paralisia. Ao invés de promover a aplicação de técnicas modernas para conservar a saúde e prevenir a doença, ele atua na direção contrária, adoecendo a população e tornando-a inerte, imóvel, estagnada. Essa ideia exprime a inércia política e cultural do país, uma vez que esse estado de imobilismo do brasileiro não contribui para elevação do seu nível de consciência, segundo afirma Santos (1999). Isso ocorre, pois, segundo György Lukács, no mesmo texto citado anteriormente:

\begin{abstract}
A burguesia possui somente a aparência de uma existência humana. Entre aparência e realidade, portanto, deve surgir em cada indivíduo da classe burguesa uma viva contradição; depende, então, em grande parte, do próprio indivíduo se ele deixará que essa contradição adormeça, por efeitos de narcóticos ideológicos que sua classe continuamente lhe ministra, ou se ela permanecerá viva nele e o conduzirá a romper inteira ou, parcialmente, os véus enganadores da ideologia burguesa. Na esmagadora maioria dos casos, naturalmente, será a consciência burguesa de classe que levará a melhor. Aqui também seu predomínio não é automático. (...) não por acaso, existe todo o aparato da crítica apologéticoromântica do capitalismo, destinado precisamente a desviar estas rebeliões e reconduzir os revoltosos ao estábulo do capitalismo (Lukács, 2010: 71).
\end{abstract}

Manter esses homens e mulheres estanques, deitados, doentes, olhando para o teto de um hospital, é reconduzi-los ao "estábulo do capitalismo". Impedidos de olhar a vida em profundidade, aceitarão o mundo como "morto e acabado", não haverá questionamentos, tampouco mudanças.

Em alguns momentos da narrativa, Ramiro lembra Brás Cubas, personagem de Memórias Póstumas de Brás Cubas, de Machado de Assis. Esta personagem de Machado cria o Emplasto que leva seu nome, que nada mais é do que um plano para obter fama. 0 emplasto é apresentado como "ideia grandiosa e útil”; "panacéia anti-hipocondríaca”; "destinado a aliviar a nossa melancólica humanidade". Assim ele é descrito no romance machadiano:

Chamei a atenção do governo para esse resultado verdadeiramente cristão. Todavia, não neguei aos amigos as vantagens pecuniárias que deviam resultar da distribuição de um produto de tamanhos e tão profundos efeitos. Agora, 
porém, que estou cá do outro lado da vida, posso confessar tudo: o que me influiu principalmente foi o gosto de ver impressas nos jornais, mostradores, folhetos, esquinas e enfim nas caixinhas do remédio, estas três palavras: Emplastro Brás Cubas. Para que negá-lo? Eu tinha a paixão do ruído, do cartaz do foguete de lágrimas. Talvez os modestos me arguam esse defeito; fio, porém, que esse talento me hão de reconhecer os hábeis. Assim, a minha ideia trazia duas faces, como as medalhas, uma virada para o público, outra pra mim. De um lado, filantropia e lucro; de outro lado, sede de nomeada. Digamos: amor da glória (Assis, 1994: 4).

Nada mais semelhante a Ramiro, que "adora remédios" e os considera "símbolos da grande humanidade sofredora que está por trás das caixas, dos rótulos, dos vidros". Se, para a personagem de Quarup a salvação do país é a drogaria, seus remédios imprimem intenções semelhantes às do emplasto: "aliviar as dores da melancólica humanidade", então, percebemos um ponto comum entre as personagens.

Ramiro, no entanto, não é um defunto autor, como é o caso de Brás Cubas e, por isso, não confessa tudo. Não confessa as duas faces de sua ideia, mas o narrador em Quarup, utilizando-se do discurso indireto livre, explicita a paixão de Ramiro pelo ruído, pelo poder, pelo holofote. Escrever uma biografia da farmácia, que também seria "um pouco da minha própria história e da minha família, como uma tese central sobre o Brasil” (Callado, 1984:125) indica essa sede de nomeada, tão cara a Brás Cubas e Ramiro.

A esperança de lucro ou mesmo a generosidade dos bons cristãos com o emplastro e a drogaria são apenas aparências, que ocultam a verdadeira intenção, como já mencionado. 0 emplasto, segundo Schwarz (2000: 23) no livro Um mestre na periferia do capitalismo, significa "o ideário liberal-burguês; a filosofia do inconsciente (em transposição cômica); o contraste entre a cura antiga e a medicina moderna; o patrocínio governamental; a finalidade cristã; a finalidade capitalista; e a síntese, na mania do anúncio, entre a velha vaidade e o novo espírito comercial".

Afirmamos aqui que a farmácia e os remédios conservados nela (tanto antigos quanto modernos) também têm esse significado de "ideário liberal-burguês, de contraste entre a cura antiga e a medicina moderna" e seus respectivos representantes têm uma intenção em comum: obter dinheiro e fama (a velha vaidade e o novo espírito comercial). No museu de Ramiro permanecem também o contraste entre a cura antiga e a medicina moderna, a velha vaidade e a necessidade de progredir, de superar a infância perpétua. Prevalecerá a velha vaidade. Esses interesses, tanto de Brás Cubas quanto os de Ramiro, aparentemente se mostram como universais, mas na verdade são singulares. Estão relacionados a uma ideia puramente individual de poder, de status. A ordem individual, criada pelo capitalismo, está explícita nos romances. As vidas de ambos se desenvolvem a parte da sociedade, como se fosse possível, e é nesta vida privada que os personagens revelam seus instintos sádicos, cínicos e egoístas. 
Entre novidades úteis e graciosas velharias: como...

Essa ideia de individualismo está ligada à história humana e é um problema de classe, portanto. Está ligada ao desenvolvimento do capitalismo, como afirmam Marx e Engels no Manifesto Comunista:

\begin{abstract}
A burguesia, onde quer que tenha conquistado o poder, destruiu as relações feudais, patriarcais e idílicas. Rasgou todos os complexos e variados laços que prendiam o homem feudal a seus superiores naturais, para só deixar subsistir, de homem para homem, o laço do frio interesse, as duras exigências do pagamento à vista. Afogou os favores sagrados da exaltação religiosa, do entusiasmo cavalheiresco do sentimento pequeno-burguês nas águas geladas do cálculo egoísta (Marx, Engels, 2010: 43).
\end{abstract}

Dessa citação, verifica-se uma outra contradição: ao mesmo tempo que a destruição das relações feudais é progresso, desenvolvimento e libertação, ela também produziu outro servilismo, o do cálculo egoísta, o frio interesse do pequeno burguês. Outra característica muito própria de Ramiro é a sede por grandes discursos. Seu amor pela denominação, pelo adjetivo, por frases feitas tornam-no um medalhão. Resgatando outro personagem da literatura brasileira, ao ouvir Ramiro falar, lembramos de Janjão, personagem do conto “Teoria do medalhão", de Machado de Assis, originalmente publicado na Gazeta de Notícias, no ano de 1881, e posteriormente integrado ao livro Papéis Avulsos.

No referido conto, pai e filho conversam sobre "coisas importantes". O pai aconselha Janjão sobre o ofício que irá escolher e assevera que nenhum lhe parece mais útil e cabido do que o de medalhão. Para sê-lo, há uma receita que deve ser seguida:

- Entendamo-nos. Condeno a aplicação, louvo a denominação. O mesmo direi de toda a recente terminologia científica; deves decorá-la. Conquanto o rasgo peculiar do medalhão seja uma certa atitude de deus Término, e as ciências sejam obra do movimento humano, como tens de ser medalhão mais tarde, convém tomar as armas do teu tempo. E de duas uma: - ou elas estarão usadas e divulgadas daqui a trinta anos, ou conservar-se-ão novas; no primeiro caso, pertencem-te de foro próprio; no segundo, podes ter a coquetice de as trazer, para mostrar que também és pintor. De outiva, com o tempo, irás sabendo a que leis, casos e fenômenos responde toda essa terminologia; porque o método de interrogar os próprios mestres e oficiais da ciência, nos seus livros, estudos e memórias, além de tedioso e cansativo, traz o perigo de inocular idéias novas, e é radicalmente falso. Acresce que no dia em que viesses a assenhorear-te do espírito daquelas leis e fórmulas, serias provavelmente levado a empregá-las com um tal ou qual comedimento, como a costureira esperta e afreguesada, - que, segundo um poeta clássico, Quanto mais pano tem, mais poupa o corte, Menos monte alardeia de retalhos; e este fenômeno, tratando-se de um medalhão, é que não seria científico.

- Digo-lhe que o que vosmecê me ensina não é nada fácil.

- Nem eu te digo outra coisa. É difícil, come tempo, muito tempo, leva anos, paciência, trabalho, e felizes os que chegam a entrar na terra prometida! Os que lá não penetram, engole-os a obscuridade. Mas os que triunfam! E tu triunfarás, crê-me. Verás cair as muralhas de Jericó ao som das trompas sagradas. Só então poderás dizer que estás fixado. Começa nesse dia a tua fase de ornamento 
indispensável, de figura obrigada, de rótulo. Acabou-se a necessidade de farejar ocasiões, comissões, irmandades; elas virão ter contigo, com o seu ar pesadão e cru de substantivos desadjetivados, e tu serás o adjetivo dessas orações opacas, o odorífero das flores, o anilado dos céus, o prestimoso dos cidadãos, o noticioso e suculento dos relatórios. E ser isso é o principal, porque o adjetivo é a alma do idioma, a sua porção idealista e metafísica. O substantivo é a realidade nua e crua, é o naturalismo do vocabulário.

(...) (Assis, 2002: 58).

Se o conto machadiano se encerra sem a conclusão sobre o futuro de Janjão, ao menos sabemos que a teoria do pai foi ouvida em algum momento. Ramiro, de fato, decora a terminologia científica e a expõe sempre que pode, ainda que haja um grande pedantismo nessa atitude:

- Que ternura - disse Ramiro - esses remédios de ontem, de uma arrogância admirável. Veja o Arsycodile de Le Prince, que em clister, injeção ou pastilha curava tuberculose, impaludismo, anemia, neurastenia, bócio e moléstias da pele em geral. Remédios da nossa infância, quando crescíamos para valer. Quando o afrancesamento chegava ao apogeu de galiqueira adquirida em fêmea gálica saíamos para a Poção de Chopart, para o xarope de copaíba de Puche, para a injeção de sândalo e resorcina de Bretonneau. Líamos Thérese Raquin e curávamos gonorreia com cápsulas e injeções de copaibato de soda do Docteur RquEn copaíba, alcatrão da Noruega, magnésia calcinada [...]

- Esses índios realmente exageram na desinteria - disse Ramiro. - E não se limpam com gravetos, como fazem os índios agrupados no Posto Capitão Vasconcelos. Aqueles, pelo menos, dariam um capítulo original De Modo Cacandi, de Tartareto.

- Os cren lá tem tempo pra graveto ou folha? - disse Olavo.

- Isso é verdade - disse Ramiro. Talvez por isso lhes falte o traço cultural do graveto. E dariam uma ilustração dramática ao famoso emético do Dr. Corvisart, feito à base do cremos do tártaro solúvel. Inimitável Corsivart! Soltava a grande Armée nos intestinos do doente (Callado, 1984: 132 e 362).

A teoria do medalhão é, portanto, "o exemplo acabado de um desejo de reconhecimento pessoal claramente identificado à frivolidade pura, à mera forma esvaziada de conteúdo, a uma aparência pomposa que se pretende divorciada da essência verdadeira" (Corrêa, 2015: 32).

Nesse desejo de reconhecimento, tão caro a Brás Cubas, tão caro a Janjão e tão caro a Ramiro, identifica-se a decadência ideológica burguesa, pois,

fundamentados em abstrações arbitrárias, deformam a realidade submetendo-a a seu bel-prazer, escondem na retórica suntuosa e no prazer do arruído a verdade de sua vida vazia de sentido, elevam a método científico seus preconceitos subjetivos, abraçam uma concepção de mundo superficial, fatalista e desumana, cujos fenômenos se apresentam em uma forma fetichizada, como um destino imutável imposto à humanidade, sem vinculação aparente com a história que se realiza pela ação concreta dos seres humanos (Corrêa, 2015: 41). 
Nesta fala do pai de Janjão, apresentada a seguir, percebe-se claramente essa deformação da realidade de acordo com caprichos e necessidades pessoais, escondida sob uma máscara de palavras suntuosas. A decadência ideológica está ligada à ideia de modernização conservadora, pois, a burguesia

entendendo que as liberdades burguesas e o progresso ameaçavam seu domínio de classe, dá as costas ao proletariado e compõe aliança com a aristocracia feudal que antes havia derrotado. Assim, a burguesia entra em sua fase apologética: para manter-se como classe dirigente, ela deve abrir mão de ser efetivamente classe dirigente, isto é, ela deixa de ser a classe que representava efetivamente todos os interesses progressistas. Ao conservar a ordem retórica, a burguesia impulsiona a inversão da ordem historicamente necessária, ela passa de participante a observadora; abandonando a representação viva dos interesses humanos (Corrêa, 2015: 40).

Ramiro também é diretor do Serviço de Proteção aos Índios (SPI) e aceita "esse abacaxi”, como ele mesmo diz, por amizade ao ministro Gouveia, mas nunca sequer visitou o Xingu. Ser diretor do SPI não indica uma causa a qual ele se dedica, mas, ao contrário, representa seus interesses em manter as ligações com o fazendeiro Gonçalo e com as companhias de terras, que avançam nas terras dos indígenas. Sente asco e desdém pela floresta, conforme nos indica o narrador:

Era asco que o diretor do SPI sentia pela floresta. Gordo, balofo, de pés pequenos e mãos delicadas podia-se esperar que tivesse medo. Mas era puro desdém. Andando ao lado de Nando, metia-se em touceiras de brenha grossa afastando galhos com a mão, mas sem se curvar, sem se humilhar. Tudo com nojo e soberba. Para não dar confiança ao mato. Tratava a floresta brasileira como uma criada (Callado, 1984: 190).

Esse desdém, a soberba, os gestos austeros, o nojo, nada é confessado por ele, mas pelo narrador, que capta esse sentimento de superioridade, essa relação entre senhor e criada que Ramiro tem com a floresta, assim como também ele e sua classe têm para a realidade. Olham a realidade com desprezo, arrogância, negando as contradições da vida. Essa forma de encarar a realidade nos dá pistas de que Ramiro é um naturalista e há muitos motivos, até mesmo já demonstrados até aqui, para se concluir isso. Antes de tudo, sua concepção cientificista, que condena a vida humana ao fatalismo e que substitui a história por conhecimentos científicos; a sua aceitação aos movimentos naturais que predeterminam o seu comportamento e os destinos humanos; sua ideia fixa em escrever uma biografia, sua tendência em ser excessivamente descritivo, como um médico legista; a máquina fotográfica que traz pendurada ao pescoço para tudo registrar e a forma de enxergar a realidade, com desdém, retratada como se fosse composta por fragmentos:

Eu sei vários nomes de orquídeas, disse Ramiro - lindíssimos. Não sei é fazê-los coincidir com as flores. Catasetum Pileatum, Galeandra Devonian. Que beleza! Catleia Luteola. Lindo!

Ramiro estava loquaz. 
Entre novidades úteis e graciosas velharias: como...

- Eu sei o nome de todas as flores que podemos encontrar por aqui.

- Não são tantas assim - disse Francisca.

- Não são? E os nenúfares, as liliáceas que florescem dentro do rio, à sombra das cachoeiras? E as sobrálias, quase orquídeas tão densas ás vezes que Shomburgk teve de abrir caminho entre elas a machadinha, seus olhos europeus cheios de lágrimas pelo sacrilégio? (...)

- Pura conversa - disse Fontoura - é que a gente só aprende o nome das coisas, o nome isolado das coisas. É o caso do Ramiro (Callado, 1984: 320).

Estres trechos revelam muito sobre Ramiro: saber os vários nomes das orquídeas, mas não os fazer coincidir com as flores revela uma visão estanque, fotográfica ou documental da realidade, nada realista. Segundo Antonio Candido,

para o Naturalismo a obra era essencialmente uma transposição direta da realidade, como se o escritor conseguisse ficar diante dela na situação de puro sujeito em face do objeto puro, registrando (teoricamente sem interferência de outro texto) as noções e impressões que iriam constituir o seu próprio texto (Candido, 2011: 7).

Esta afirmação sobre o Naturalismo corrobora com Ramiro, nos seus registros dos nomes isolados das coisas, na sua posição de observador. No Naturalismo, as personagens e enredo, estão submetidos a um destino cego das leis naturais que a ciência da época julgava ter codificado:

As obras estruturalmente naturalistas limitam-se à descrição do mundo convencional e vazio, isto é, à reprodução superficial de ambientes e de indivíduos médios (cotidianos). Trata-se da primeira manifestação literária da decadência burguesa, de uma época na qual a rígida divisão capitalista do trabalho, alienando os homens com relação à história, dificulta-lhes uma visão de conjunto da realidade global. O naturalismo limita-se a reproduzir a superfície da realidade, jamais transcendendo o fenômeno empírico imediato (Coutinho, 1978: 73).

Antonio Candido em Literatura e Subdesenvolvimento (2017: 181) afirma que o naturalismo foi a tendência estética peculiar a uma época onde triunfava a mentalidade burguesa e correspondia à consolidação das nossas literaturas. Segundo o crítico, o Naturalismo no romance chegou tardiamente ao Brasil e se prolongou, devido ao fato de estarmos entre os países "que na maior parte têm problemas de ajustamento e luta com o meio". Nesses casos, Candido apregoa, o peso da realidade local produz uma espécie de legitimação da influência retardada, que adquire sentido criador. Enquanto que "na Europa o Naturalismo era uma sobrevivência, entre nós ainda podia ser ingredientes de fórmulas literárias legítimas, como as do romance social dos decênios de 1930 e 1940". (Candido, 2017: 181).

Qual é, portanto, a necessidade desta composição naturalista do personagem, em um romance escrito na década de 60 ? Porque o Naturalismo ainda é ingrediente de fórmulas literárias legítimas? Lukács (2010) em Narrar ou Descrever, afirma que a ciência burguesa do século XIX, investida de uma função apologética e 
fatalista, enxergava a realidade de uma maneira bastante diversa, de modo que toda revolução, ou todo passo à frente, lhe aparecia como algo catastrófico e anormal. A literatura naturalista, baseada na descrição e na observação, primeira manifestação literária da decadência burguesa, limitada à descrição do mundo convencional e vazio, eliminava, portanto, "o intercâmbio entre a práxis e vida interior", deformando a realidade:

O método descritivo é inumano. $O$ fato de que ele se manifeste, como vimos, na transformação do homem em natureza-morta é só um sintoma artístico de tal inumanidade. A inumanidade se revela plenamente nas tentativas de formulação ideológica-estética dos principais representantes dessa orientação (Lukács, 2010: 177).

Ramiro pode, então, ter sido construído para questionar a própria literatura. Em um momento histórico tão significativo e repleto de contradições, quanto ao que fora escrito o romance de Callado, ao nos defrontar com Ramiro, surge-nos o questionamento: qual é o papel da arte? Caberia ao escritor, naquele momento, optar pela observação dos fatos ou tomar uma posição diante deles, dando um passo à frente, mostrando uma perspectiva à realidade apologética e fatalista que Ramiro transfigura?

Se, para a personagem, todo passo à frente lhe parece como algo catastrófico e anormal, sua composição fala muito da realidade brasileira, fala muito da história do país, da sua formação e suas contradições e fala muito também da classe que ele representa. Além disso, a obra não reflete estas questões de maneira direta, como pretendiam os naturalistas. Callado internalizou no texto e na sua própria forma de narrar

uma potente crítica à visão de mundo e à composição estética naturalistas. O método [de Ramiro] é hiperdeterminado, é naturalista, no sentido de que representa algo decorrente de uma visão deformada da realidade pelos caprichos de uma classe engaiolada na sua própria contradição insolúvel e que deseja manter a vida e o andamento da história entrincheirados nos limites de seu projeto estanque, interessado, fútil e vazio de futuro (Corrêa, 2020: 84).

Atuam em Ramiro duas forças opostas: a primeira, que vem do método de composição dos traços psicológicos que caracterizam a personagem e a segunda força, que vem da própria composição desta personagem, mas que se supera e dá um passo à frente. Esta segunda força seria a forma de um personagem, como Ramiro, dar conta de falar de uma realidade contraditória e viva.

Após este capítulo em que Ramiro nos é apresentado junto a sua farmácia, o romance dá um salto de alguns anos e o veremos no Xingu. Não é por vontade que aceita ir ao Xingu, pela primeira vez, mas, para tratar da ida do presidente da república, Getúlio Vargas, que promete inaugurar o parque nacional. Esse momento do texto é significativo, como veremos na descrição a seguir: 
Na madrugada do Tuatuari, pálido, nu, à beira do rio fervente de selvagens, Ramiro parecia o próprio desalento brotando como um cogumelo na era paleolítica:

De uma eminência, Ramiro olhou a região em torno, o Tuatuari coleando pela planura, uma ponta distante da lagoa Ipavu, a barreira verde da Amazônia. Balançou a cabeça como quem vistoria um descalabro. Parecia prestes a brandir um vassourão, um rodo, um balde e começar a enxaguar, limpar e arrumar a gigante bagunça do Planalto Central brasileiro (Callado, 1984: 191).

"Ramiro era o próprio desalento brotando como um cogumelo na era paleolítica”. Essa descrição corrobora com o clima ideológico do país, com o sentimento desolador trazido pela ditadura militar, com o retrocesso que o Brasil caminhava. A personagem, em quase todos os momentos que aparece na narrativa, exceto quando embriagado, tem um ar tendendo ao triste, ao tédio, ligado a sentimentos saudosistas e pessimistas.

Para suportar o tédio, procura encontrar melhoramentos para aquela região e fica "extremamente desgostoso" com o setor de socorros médicos:

- A apresentação é péssima! Essas prateleiras de caixotes, vidros e caixinhas jogados aí de qualquer jeito. Os índios deviam entrar aqui como se entrassem em uma igreja. Com unção e respeito. Pelo que poderíamos fazer por eles no plano da doença, eles poderiam nos adorar.

Para que aceitem nossa civilização e nosso Deus, têm de se aproximar de nós como se fossemos seres superiores, capazes de indicar a eles caminhos novos. E não há momento melhor para isto do que aquele em que os índios estejam vivificados pela doença. Este é o instante de impressioná-los (Callado, 1984: 194).

Esta fala denota, mais uma vez, sua inadequação às ideias da época em que vive. Soa como o colonizador europeu que chegou ao território brasileiro impondo suas crenças, seus valores e seus costumes aos indígenas, sentindo-se superior a eles. Mostra também, mais uma vez, seu desejo de glória. Ser adorado, glorificado pelos remédios é sua intenção mais profunda. Sua ideia, no entanto, é ainda maior: fazer no posto do SPI e nos demais postos, réplicas da Farmácia Castanho ou, nas palavras do próprio personagem, construir: "no mar de brenha burra e saudável, portos de progresso". Seria, segundo ele, "a evolução do cigarro misterioso do Pajé à teologia estruturada numa Farmácia Castanho":

- Me diga, Nando, que espécie de medicina têm os bugres?

- Dependem do pajé pra tudo e o pajé depende do fumo para curar tudo. Fica soprando a fumaça dos cigarros compridos em cima do baço inchado de malária ou de qualquer outro órgão afetado de qualquer outra forma.

- Mas aí está um elemento importante...

Ramiro se deteve, perdido em meditação.

- E há ervas - começou Nando - que...

- Minha ideia - disse Ramiro - é fazer aqui neste posto e nos demais réplicas da Farmácia Castanho. Você sabe que todos nós temos uma certa aspiração à imortalidade. Tola, se você quiser, mas aí está. E ataca em geral quando o 
Entre novidades úteis e graciosas velharias: como...

amor nos põe a serviço de uma mulher, não acha? Não, claro, não é o meu ramo. Mas acredite que é assim. O amor exige que realizemos todas as nossas potencialidades. Truques da natureza. Por interesse em fascinar alguém, damos tudo o que temos dentro de nós a todos, à humanidade, à coletividade. Abrimos as plumas ao sol, como pavão, a garganta à lua, como o rouxinol. A mim, meu amor me põe a serviço da doença fecundante e quero que os índios compreendam que só serão homens no dia em que perderem essa cara de bobos que riem de tudo. E é preciso que entendam a reverência com que tratamos os estados mórbidos, dos quais o amor não correspondido é o primeiro, naturalmente. Isto, porém, só entenderão quando bem mais sofridos. O que desde já quero que aprendam é o conceito sagrado da enfermidade em geral.

Ramiro se deteve, pela primeira vez, abrindo uma trégua com a selva. Fez um gesto largo com a mão:

- Imagine isto cheio de Farmácias Castanho. No mar de brenha burra e saudável, portos de progresso (Callado, 1984: 194-195).

O poder da farmácia aparece novamente e sua potencialidade de modernizar com novidades úteis, mas "sem tocar nas graciosas velharias". Há uma tentativa de modernizar as áreas onde não havia chegado a modernização, mas há também um conteúdo reacionário, que torna ambígua essa intenção. Ramiro não quer simplesmente ajudar os indígenas e aumentar o suprimento de remédios que eles dispõem. Seu desejo é mais individual do que coletivo. Está em jogo os seus interesses, interesses de sua classe.

A intenção é aumentar seu poder, é estender seus domínios, é tornar-se superior em um local que ele tanto despreza e sentir-se "picoso, pluvial", adjetivos criados por ele próprio é "abrir as plumas ao sol e a garganta à lua”. Esse individualismo da personagem faz parte da ideologia burguesa mais antiga e obsoleta, centrada no indivíduo, em suas tradições. E é esse mesmo sentimento individualista que o fará seguir com a expedição composta por Nando, Francisca, Fontoura e Lauro, ao centro do país. $O$ intuito desta expedição é pacificar as tribos indígenas ainda desconhecidas e chegar ao Centro Geográfico, mas, para Ramiro, a intenção é encontrar Sônia, a mulher que ele dizia amar, e que, não cedendo aos seus domínios, fugiu com o índio Anta e nunca mais fora vista.

A partir de então, a missão de Ramiro é encontrar Sônia. Torna-se obsessivo nesta empreitada. Desse amor não correspondido, nem mesmo os remédios da sua farmácia conseguem curar a sua insatisfação, suas angústias, a dor da humanidade. Mais uma vez, seu discurso recorda o passado e o atualiza:

Nada tem importância diante de algum amor não correspondido. $\mathrm{O}$ mundo inteiro ri quando se diz essa verdade. Ri de medo dela. É uma humilhação que ninguém quer confessar. Todo mundo tende a achar que é uma velharia, uma coisa do passado da espécie. No entanto, não há dor maior (Callado, 1984: 228).

Na expedição, Ramiro não pensará em outra coisa e andará para frente, acompanhando a expedição, mas com a cabeça voltada ao passado. Na ânsia de esquecer Sônia, "atira-se a velhos cadernos de endereço, em busca de amores que julgava enterrados” (Callado, 1984: 280), o que não causará efeitos. Uma angústia 
arcaica o ameaçará em todo o percurso, na esperança vã de, em cada tribo, encontrar seu objeto de desejo, o que não se realizará, frustrando a personagem.

A figura de Ramiro em si é contraditória e nela convivem os inconciliáveis: o moderno e o apego à tradição. Vive uma vida imutável ou, em outros termos, "do mundo moderno vem a convicção de que só conta o que faz e do antigo vem o privilégio, o emprego, no qual mover-se muito seria falta de naturalidade" (Schwarz, 1978: 19). A personagem, evocando saudosamente o que já passou, escreve poemas em versos alexandrinos em homenagem às suas memórias:

Aproximou-se, interessado, e cheirou a flor.

- Esta eu conheço mesmo, é uma aristolóquia. Tive uma trepadeira dessas em casa. Mamãe mandou derrubá-la por causa do mau cheiro.

Todos aspiraram a flor linda e fétida.

- Na tristeza em que caí quando não encontrei mais minha trepadeira - disse Ramiro - escrevi in memoriam um soneto em alexandrinos. $O$ fecho de ouro celebrava "a graça fedorenta das aristolóquias".

- É isto - disse Fontoura - no Brasil a gente só consegue identificar as coisas que fedem muito (Callado, 1984: 322).

Carrega consigo em toda a expedição uma mala de remédios, parte da coleção que guarda em sua farmácia (sinal de sua hipocondria, que já é algo transparente) e um vestido cor-de-rosa com florões brancos, que Sônia vestia antes de desaparecer (um "vestido histórico", como ele mesmo afirma). Com isso, ele mostra suas posses e, em muitos momentos, faz gestos de proprietário na floresta, que contrastam com sua aparência já decadente, fraca e amarela: "Ramiro tinha o olhar esgazeado, os gestos inseguros, o rosto lívido, feições repuxadas, os bigodes crescidos. Estava mais gordo, amarelo, e dava a impressão de que, se fosse tocado por um dedo, ia ganir de dor" (Callado, 1984: 323).

Ao fim da expedição, após chegarem ao centro do país, a única certeza que temos sobre Ramiro é que ele não encontrou Sônia, mas deixou o vestido pendurado a um mastro de bandeira, tremulando ao vento, no lugar da bandeira do Brasil que os personagens esqueceram de levar. No último capítulo o leitor se intera, ainda que superficialmente, do destino da personagem, que foi procurar por Sônia em Paris, às margens do Rio Sena. Quanto à farmácia Castanho, não há mais nenhum relato ou vestígio.

O método que Ramiro utiliza para amar não é realista. Os passos que levam o amor à pessoa amada são desconectados e a figura de Sônia corresponde a mais um capricho, é apenas um detalhe, um prêmio, uma posse. Torna-se conveniente amá-la. Tanto, que Ramiro vai viver na França, local que sempre valorizou, com o pretexto de encontrar seu objeto de desejo, mesmo sabendo da impossibilidade de encontrá-lo por lá.

Permanecerá desconectado das questões sociais do seu país, isolado do mundo. Ramiro é o mesmo do início da narrativa: os traços não variaram, nada produziu e 
mais uma vez, entre o passado e o presente, não houve transformação radical. Ele pode ser considerado um personagem de costume que, de acordo com Antonio Candido (1976), seria aquele apresentado por meio de traços distintivos, fortemente escolhidos e marcados. Esses traços são geralmente utilizados na caracterização de personagens cômicos, pitorescos, invariavelmente sentimentais ou acentuadamente trágicos. Personagens, em suma, dominados com exclusividade por uma característica invariável e desde logo revelada.

O final da personagem, bem como sua força, está nas não-realizações: Ramiro não encontra o amor; não consegue expandir a farmácia; não obtém fama; não tem filhos, ou seja, nada constrói e seus caprichos também não se realizam. Ele tem apenas a ilusão de uma existência humana. Essa "falha" pode ser entendida, segundo Schwarz (tratando sobre Brás Cubas) "em sentido metafísico (a precariedade do espírito humano em geral); e em termos da história contemporânea (como peculiaridade e sinal de atraso da sociedade brasileira)". Ramiro aproximase mais uma vez do personagem Brás Cubas nas suas não-realizações:

Não alcancei a celebridade do emplastro, não fui ministro, não fui califa, não conheci o casamento. Verdade é que, ao lado dessas faltas, coube-me a boa fortuna de não comprar o pão com o suor do meu rosto. Mais, não padeci a morte de dona Plácida, nem a semidemência de Quincas Borba. Somadas umas coisas e outras, qualquer pessoa imaginará que não houve míngua nem sobra e que não saí quite com a vida. E imaginará mal; porque ao chegar a este outro lado do mistério, achei-me com um pequeno saldo, que é a derradeira negativa deste capítulo de negativas: - não tive filhos, não transmiti a nenhuma criatura o legado de nossa miséria (Assis, 2017: 178).

A diferença entre Brás Cubas e Ramiro está na confissão do primeiro, que não ocorre com a personagem de Quarup. Ramiro nada confessa e talvez nem se dê conta das suas não-realizações, o que compete ao narrador explicitar. Já Brás Cubas tem a consciência de que sua vida terminou em desolamento, em nada. Como já mencionado, assim como no romance de Machado de Assis, esse efeito desolador apresenta semelhança com o clima ideológico do país que, entre avanços e retrocessos; movimentos pendulares, reflete "a minituarização ou o diagrama do vaivém ideológico da classe dirigente brasileira" (Schwarz, 1987:133)

Ao se conectar com a história viva e contraditória, o fazer artístico capta a historicidade e revela uma realidade mais profunda e verdadeira, mas isso não significa que o romance necessite ser engajado para permitir momentos de percepção sobre a realidade. Não são os discursos grandiloquentes de Ramiro que nos dizem sobre esse mundo, mas as suas ações, o que está por trás da fachada. Os traços individuais de Ramiro, ligados aos problemas gerais do país, estão também ligados a uma classe e alçam voo, ligando-se à realidade social e seus grandes e (ainda) insuperáveis problemas.

Diante do que foi analisado, afirmamos, também, que essa objetividade retratada pela arte não se confunde com a imediatez da realidade objetiva, ou seja, não há uma associação direta entre os fatos narrados e a realidade histórica. Esses 
personagens aqui analisados não falam diretamente sobre a realidade, como uma obra naturalista, mas "põe em evidência a condição humana às voltas com os fatores sociais que bloqueiam as possibilidades de desenvolvimento humano “(Frederico, 2013: 91).

Ao iluminar as contradições que são difíceis de ser encaradas na realidade concreta, Quarup caminha entre as minúcias e o todo, o fundo e a superfície. Quarup é atual porque os fatos não mudaram muito e Ramiros ainda são possivelmente reconhecíveis na realidade; porque o país avança pouco e comedidamente, de acordo com a lógica da modernização arcaica; porque se fundamenta no embate entre dominantes e dominados; exploradores e explorados; os que mandam e os que obedecem; os que se beneficiam da modernização e os que são excluídos do processo modernizador.

É realista pois "desfetichiza a aparência triunfante do projeto determinista de vida, mundo e nação da classe dominante brasileira (articulada ao processo histórico global) e traz à superfície a sua essência real: o quanto é vazio, irracional e engaiolado o projeto falido, mas dominante, das elites" (Corrêa, 2020: 88). 


\section{Q Bibliografia}

" Machado de Assis, Joaquim (1994). Memórias Póstumas de Brás Cubas. Rio de Janeiro: Editora Nova Aguilar.

"Machado de Assis, Joaquim (2002). Contos Machado de Assis. (Coleção Grandes leituras). São Paulo: FTD.

"Callado, A. (1984). Quarup. Rio de Janeiro: Editora Nova Fronteira.

"Candido, A. (1976). A personagem de ficção. São Paulo: Perspectiva.

"Candido, A. (2000). Literatura e Sociedade. Coleção Grandes nomes do pensamento brasileiro. São Paulo: Publifolha.

" Candido, A. (2011). De cortiço a cortiço. En Azevedo, Aluísio. O cortiço. São Paulo: Expressão Popular.

"Candido, A. (2017). A educação pela noite e outros ensaios. Rio de Janeiro: Ouro sobre azul.

"Candido, A. (2017). Literatura e Subdesenvolvimento. En A educação pela noite e outros ensaios. Rio de Janeiro: Ouro sobre azul.

" Corrêa, A. L. Reis. (2015). As duas faces das medalhas: dialética aparência e essência em "Teoria do medalhão" e "O emplasto". En O eixo e a roda, Belo Horizonte, v. 24, n. 2, p. 31-47.

"Corrêa, A. L. Reis. (2020). No meio daquele cemitério brincava um raio de sol": sátira e malandragem em um conto de Machado de Assis. Em Cerrados, Brasília, n. 52, p. 78-115.

" Coutinho, C. N. (1978) Graciliano Ramos. En Brayner, Sônia (org.). Graciliano Ramos. 2. ed. Rio de Janeiro: Civilização Brasileira.

"Frederico, C. (2013). A arte no mundo dos homens. São Paulo: Expressão Popular.

" Holanda, S. Buarque. (1995). Raízes do Brasil. São Paulo: Companhia das Letras.

"Jaguaribe, Helio. (1989). Alternativas do Brasil. José Olympio.

" Lukács, G. (1978). Introdução a uma estética marxista. 2.ed. Rio de Janeiro: Civilização Brasileira.

"Lukács, G. (2010). Marxismo e teoria da Literatura. São Paulo: Expressão Popular.

"Magalhães, B. (2001). O deslocamento da posição do sujeito: uma análise do personagem Fabiano, de Vidas Secas, de Graciliano Ramos. Revista do GELNE Vol. 3 No. 1

"Marx, K.; Engels, F. (2010). Manifesto do Partido Comunista. Companhia das Letras.

"Ortiz, R. (1991). A moderna tradição Brasileira. Editora Brasiliense.

"Ribeiro, D. (2006). O povo brasileiro. A formação e o sentido do Brasil. Companhia de Bolso.

"Rosa, D. (2015). Poesia e história em Pedro Páramo, de Juan Rulfo. Curitiba: Blanche.

"Santos, F. V. (1999). Callado no lugar das ideias. Um romance de tese. Rio de Janeiro: Caetés.

"Schwarz, R. (1977). Ideias fora do Lugar. En Ao vencedor, as batatas. São Paulo: Duas Cidades. 
Entre novidades úteis e graciosas velharias: como...

"Schwarz, R. (1978). O pai de família e outros estudos. Rio de Janeiro: Paz e Terra.

" Schwarz, R. (1987). Complexo, moderno, nacional e negativo. En Que horas são? São Paulo: Companhia das Letras.

"Schwarz, R. (2000). Um mestre na periferia do capitalismo. São Paulo: Duas cidades. 